\title{
Research on the Influence of Investor Experience and Investment Strategy on Investment Return
}

\author{
Jitao $\mathrm{Hu}^{1,{ }^{*}}$ Longying $\mathrm{Hu}^{2}$
}

\author{
${ }^{1}$ Harbin Institute of Technology 1 \\ ${ }^{2}$ Harbin Institute of Technology 2 \\ *Corresponding author. Email: hujt@oimcl.com
}

\begin{abstract}
With the public's response to "mass entrepreneurship and innovation" and the gradual regulation of the financial market, venture capital industry in China has developed rapidly in recent years, which not only stimulates economic growth, but also promotes technological progress. However, there are still big differences in the performance of different venture capital entities. In this paper, we take the investment events of 540 private equity investment funds established in my country from 2008 to 2018 as a sample, and attempt to examine the impact of the investor experience and investment strategy of my country's venture capital institutions on investment returns. Through correlation analysis, hierarchical regression analysis and robustness test of variables, the empirical results show that: the investor experience of venture capital institutions is positively correlated with investment returns; industryspecialized investment strategies have a convex relationship with investment returns; regionally-specialized investment strategies have no correlation with investment returns.
\end{abstract}

Keywords: Private equity investment fund, Investor experience, Investment strategy, Investment return

\section{INTRODUCTION}

Venture capital emerged in the United States in the 1940s. As a tool to provide financial support to entrepreneurs, it plays an important role in the development of economy, technology, and industry. The rise of venture capital industry in China can be traced back to the leading implementation of the government's technology industry policy, which has grown and grown in the process of economic and industrial development and transformation [1]. With the gradual improvement of the Chinese market and policies, the venture capital industry has gradually moved forward. According to statistics from Zero2IPO Research Center, there will be more than 3,000 investment cases in China's private equity investment market in 2020 , and the amount of investment disclosure will be close to 700 billion yuan. Venture capital funds mainly invest in companies with certain technologies or innovations, and play an important role in promoting technology and innovation [2]. However, the current investment returns between different venture capital funds differ significantly. It is reported that the average rate of return of venture capital funds in China is close to 30\%, and only about one-third of the venture capital funds' returns exceed the break- even point [3]. Therefore, issues related to the investment returns of venture capital funds have attracted more and more attention from the academic community. One of the focuses that scholars pay attention to is the relationship between the characteristics of venture capital funds, investment strategies and investment returns. At present, there is no consensus on the research conclusions in this regard. In addition, the relevant research in the Chinese settings is not sufficient. Based on the above practical and theoretical issues, we use the data of 540 private equity investment funds in China to invest in the expansion period as a basis to conduct empirical research on the relationship between some characteristics of venture capital funds, investment strategies and investment returns.

\section{LITERATURE REVIEW}

At present, from the perspective of management, the main areas involved in the research on the investment return of venture capital funds include the personal characteristics displayed by the fund [4] and organizational characteristics [5]. However, the conclusions of previous research are quite controversial, 
so more in-depth research is needed on the relationship between the characteristics of venture capital funds and investment returns.

\subsection{Research on Investor Experience and Investment Return of Venture Capital Fund}

In terms of research on the relationship between investor experience and investment returns of venture capital funds. Siqueira and Carvalho (2011) [6] studied the influencing factors of the investment return of venture capital funds, and believed that the investment return of venture capital funds depends on the fund size, investment experience, etc., and believed that investment experience and investment return are positively correlated. Zarutskie (2010) [7] examined the relationship between the human capital of the management team of venture capital funds and the return on investment, and found that the richer the investment or entrepreneurial experience of the management team, the greater the proportion of successful exits in the portfolio. Nan J and Wei L (2014) [8] used the investment data of Chinese venture capital funds as a sample, and proved that the diversified investment of venture capital funds with rich experience is positively correlated with investment returns. $\mathrm{Xi} \mathrm{H}$ (2009) [9] and Gompers (2010) [10] believe that there is a positive correlation between specialization and investment returns, that is, the human capital of venture capital funds plays an important role in bringing good investment returns. Bottazzi (2008) [11] found that venture capital teams with past business experience can more actively recruit executives, raise funds, and interact more frequently with the companies they invest in. Srensen (2008) [12] found that companies with more extensive experience in venture capital investment institutions are more likely to go public, which will also mean that venture capital institutions with experience have better investment returns. Bengtsson and Sensoy (2011) [13] believe that more experienced venture capital institutions have excellent monitoring and valueadded capabilities, and they may join the board of directors of the companies they invest in more frequently. Compared with underexperienced venture capital institutions, gain The weaker downside protects contractual cash flow rights. On the contrary, Fang et al. (2018) [14] found that the investment return of venture capital funds has nothing to do with the manager's investment experience.

\subsection{Research on Investment Strategy and Investment Return of Venture Capital Fund}

Regarding the investment strategy of venture capital funds, some scholars have carried out research on specialized investment strategies. Gompers and Kovner (2009) [15] studied the relationship between the degree of specialization of venture capital firms and their success, and found a strong positive correlation between the two. In addition, the market performance of experienced venture capital institutions tends to be better. Nan and Wei (2014) [8] found that industry specialization has a significant positive impact on the return of venture capital. Deng and Liu (2017) [16] studied the relationship between the industry specialization intensity of venture capital institutions and the innovation capability of target enterprises. It is found that there is a significant positive impact between the two. Huang et al. (2016)[17] found that the industry specialization of venture capital has a greater impact on the technological innovation produced by high-tech companies, while the stage and geographical specialization investment strengthens the impact of industry specialization on technological innovation; In addition, industry specialization has promoted the occurrence of early and short-distance investment behaviors of venture capital institutions, and there is a partial mutual promotion between different specialized investment strategies. Li et al. (2012) [18] found that when the professional investment of venture capital institutions is consistent with the industry in which the enterprise is located, the investment success rate will increase accordingly. Dang et al. (2014) [19] found that industry specialization and stage specialization have a significant positive impact on the investment returns of venture capital institutions. There is no significant relationship between geographic area specialization and investment returns of venture capital institutions, and industry specialization has the greatest impact on the investment returns of venture capital institutions. The research of Shen and $\mathrm{Hu}(2014)$ [20] found that the industry or geographic specialized investment of venture capital institutions has a significant promotion effect on the investment return, while the stage specialization investment has no significant effect on the investment return. They believe that the positive relationship between professional investment and investment returns is not only caused by the risk factors associated with the strategy, but also related to the investment experience and skills accumulated by adopting the investment strategy. On the contrary, Bartkus and Hassan (2009) [21] found that focusing on a specific stage of development has a negative and significant impact on the success rate of the portfolio. Industry specialization has no significant impact on the success rate of venture funds.

In addition, some scholars have conducted research based on diversified investment strategies. Buchner et al. (2017) [22] found that when venture capital funds are operated by experienced managers, investments in diversified industries and stages will generate higher returns. The expected negative impact of diversification on fund risks has prompted fund managers to choose riskier investments endogenously, leading to better performance of diversified funds. Norton and 
Tenenbaum (1993) [23] found that venture capitalist portfolios can reduce non-systematic risks by investing in diversified companies or industries. By controlling the investment of transactions at different stages, the investment portfolio can also be diversified to deal with market risks. His research supports the view that venture capitalists control portfolio risk through efforts to specialize, build reputation capital, and become an important member of the information and transaction flow network.

In summary, it can be seen that many scholars have focused their attention on the relationship between the characteristics of venture capital funds, investment strategies and investment returns. However, the current research conclusions on this direction are not unified, and empirical research is still insufficient in our country, which prompts us to conduct in-depth research on this topic.

\section{METHOD}

\subsection{Research design}

\subsubsection{The hypothesis of the research}

Resource-based theory believes that enterprises are usually composed of tangible and intangible resources, and these resources can be transformed into special capabilities. Resources are immobile and difficult to replicate among enterprises. In addition, the theory of enterprise growth believes that an enterprise is a management organization and a collection of human and material resources. The internal resources of the enterprise are the driving force for the growth of the enterprise. For venture capital funds, these distinctive features and resources have long been used by scholars to study the relationship between investment returns. However, the current scholars' views are still widely inconsistent. Therefore, through the above discussion, we formulate the research questions as follows: (1) What is the relationship between the investor experience of venture capital funds and the return on investment? (2) What is the relationship between the investment strategy of venture capital funds and investment returns?

Kanniainen and Keuschnigg (2004) [24] found that the key to promoting the development of the venture capital industry is venture capital companies with management and knowledge. Venture capital is a knowledge-intensive industry. Whether the invested projects can achieve exit and profitability, especially the knowledge and skills of venture capital. Unlike Fang et al. (2018) [14] who believe that the investment return of venture capital funds has nothing to do with the team experience, according to Zarutskie (2010) [7] and Srensen(2008) [12], we believe that the richer the investor experience of venture capital funds, The better the return on investment. Therefore, we propose the following assumptions:

H1: The investor experience of venture capital funds is positively correlated with investment returns.

Entrepreneurship and the market environment are constantly changing. Start-ups may be forced to move to an unfamiliar field. At this time, the capabilities and knowledge of non-diversified venture capital institutions may not be able to meet the development needs of startups. That is, in an uncertain environment, the adaptability and flexibility of venture capital institutions that adopt specialized investment strategies appear to be weak (Matusik and Fitza (2012) [25]). And venture capital institutions that adopt diversified investment strategies often have a strong ability to solve complex problems. A diversified knowledge reserve not only provides a larger choice space for finding solutions to problems (Ahuja and Katila (2001)[26], March (1991)[27]), it also provides a basis for analogical thinking. Sexual thinking helps venture capital institutions to obtain better solutions (Gavetti et al., (2005)[28]). Secondly, venture capital institutions that adopt diversified investment strategies need to coach startups in multiple industries and fields. This ability is particularly important for the development of startups. Start-up companies are often faced with huge uncertainty, which puts forward higher requirements on the flexibility and adaptability of venture capital institutions. Venture capital institutions that adopt diversified investment strategies are better able to supervise and guide startups in this environment [25]. We believe that when venture capital is small in scale, cross-industry investment experience and funds are abundant, and specialized and centralized investment strategies will be better than diversified investment strategies. Larger investment institutions adopt diversified investment. The strategy is to diversify more investment risks and create higher returns. Therefore, we propose the following assumptions:

H2: The industry-specific investment strategy of venture capital funds has a convex relationship with investment returns.

H3: The geographically specialized investment strategy of venture capital funds has a convex relationship with investment returns.

\subsubsection{Model design}

The main purpose of this paper is to explore whether the characteristics of venture capital funds and investment strategies affect investment returns. We established three models as follows: Model (1) examines the impact of venture capital funds' investment experience on investment returns; Model (2) jointly examines venture capital funds' investment 
experience, industry-specific investment strategies, and geographic regions The impact of specialized investment strategies on investment returns; Model (3) jointly examines the influence of the logarithm of venture capital funds' investment experience, industry specialized investment strategies, geographic specialized investment strategies, and industry specialized investment strategies on investment returns.

Model $1: y_{1}=\beta_{0}+\beta_{1} \times \exp +\varepsilon$

Model 2: $y_{2}=\beta_{0}+\beta_{1} \times \exp +\beta_{2} \times$ Industryhhi $+\beta_{3} \times$ Regionhhi $+\varepsilon$

Model 3: $y_{1}=\beta_{0}+\beta_{1} \times \exp +\beta_{2} \times$ Industryhhi $+\beta_{3} \times$ Regionhhi $+\beta_{4} \times \ln ($ Industryhhi $)+\varepsilon$

\subsection{Data}

The data in this paper comes from the Zero2IPO database, which covers data on venture capital and private equity investment markets in China since 1990. The data processing software is Python. Based on the data of investment in venture capital funds established in 2008-2018 in the Zero2IPO database, we carry out the following four steps to further select sample venture capital funds: (1) Exclude venture capital funds with foreign-funded backgrounds. We divide venture capital funds into domestic-funded and foreign-funded backgrounds from the perspective of investment and holding. This paper is limited to the analysis of venture capital funds with domestic-funded backgrounds; (2) Cancellation of venture capital funds established after 2018. We consider the exit ratio of venture investment portfolios. According to Qian and Zhang (2007) [1], the average exit time of venture investment portfolios in my country is 2.25 years. In addition, $\mathrm{Ni}$ and Sun (2008)[29] stated that the exit time of venture capital funds in China is about 1.97 years. Given that the latest sample data is 2020, a two-year lag can be regarded as a reasonable time for the fund to complete its exit. (3) Exclude private equity funds whose filing types are "Private Securities Investment Funds" and "Trust Plans"; (4) Exclude event data that have not disclosed relevant information and data investment.

According to the above criteria, we consult the relevant venture capital fund website and fill in the missing data. The final sample is composed of 540 funds from 2008 to 2018. Then, we collect relevant data from the Zero2IPO database, including fund age, fund background, fund size, fund management institution and the total number of funds under management, fund investment industry, fund investment region and exit event data.

\subsection{Variable definition}

This summary defines all the variables used in this paper, as shown in Table 1:

Table 1. Definition of variables

\begin{tabular}{|c|c|c|}
\hline Types & Variables & Definitions \\
\hline Dependent variable & Investment Return $\left(y_{1}\right)$ & Measured by the fund's average internal rate of return \\
\hline \multirow{3}{*}{ Independent variable } & $\begin{array}{l}\text { Investor's experience } \\
\text { (experience) }\end{array}$ & $\begin{array}{l}\text { It is expressed by [the historical investment amount of the fund in the } \\
\text { end of the investment year+1] minus [the average historical investment } \\
\text { amount of each fund in my country's PE market in the end of the } \\
\text { investment year+1] }\end{array}$ \\
\hline & $\begin{array}{l}\text { Industry specialization } \\
\text { (industry) }\end{array}$ & $\begin{array}{l}\text { Measured with the Herfindahl-Hirschman index, the calculation formula } \\
\text { is } \mathrm{HHI}=\sum P_{i}^{2}, P_{i} \text { is the proportion of each fund's various invested } \\
\text { industries. }\end{array}$ \\
\hline & $\begin{array}{l}\text { Regional specialization } \\
\text { (region) }\end{array}$ & $\begin{array}{l}\text { Measured with the Herfindahl-Hirschman index, the calculation formula } \\
\text { is HHI }=\sum P_{j}^{2}, P_{j} \text { is the geographic gap between the fund establishment } \\
\text { address and the invested company. The variable for the same province is } \\
\text { set to " } 1 \text { ", and the variable for different provinces is set to " } 0 \text { ". }\end{array}$ \\
\hline \multirow{3}{*}{ Control variable } & Fund type (type) & Exclude funds whose capital type is foreign \\
\hline & $\begin{array}{l}\text { Investment stage } \\
\text { (stage) }\end{array}$ & Select investment events and exit events during the expansion period \\
\hline & Fund age (age) & Select PE funds established between 2008 and 2018 \\
\hline
\end{tabular}




\section{(1) Explained variable}

The exit methods of venture capital mainly include IPO, equity transfer (M\&A or repurchase), liquidation and bankruptcy. Among them, IPO is considered to be the most ideal exit method, equity transfer is the best choice when companies cannot go public, and both are considered as the main channels for venture capital to obtain returns. Due to the lack of private equity investment transaction data in the secondary or public markets, and the pricing of such investments is not publicly disclosed, analysts usually use the internal rate of return and multiples of private equity investment funds to confirm returns. Therefore, when venture capital is withdrawn through IPO or equity transfer, an investment event is considered to be successful. We refer to the research of Liu (2014) [30] and uses the average internal rate of return of the fund to measure the return on investment.

\section{(2) Explanatory variable}

The team experience of a venture capital fund is mainly determined by the human capital of the institution. However, due to limited public data on human capital, it is not easy to measure. Therefore, we use the investor experience of venture capital funds as a measure of its characteristics. In order to reflect the relative characteristics of venture capital funds, we have adjusted the average value of investment experience. The specific adjustment method is: the investor experience of a venture capital fund is equal to the number of enterprises invested by the venture capital fund as of the investment year minus the average number of enterprises invested by each venture capital fund in my country's venture capital market as of the investment year (Wang and Wang (2011) [31]). The investment strategies of the funds studied in this paper include industry specialization strategies and geographic specialization strategies, both of which are measured by the Herfindahl-Hirschman index. The formula for calculating the degree of industry specialization is $\mathrm{HHI}=$ $\sum P_{i}^{2}$, where $P_{i}$ is the proportion of each fund's investment in various industries. According to the "2018 China Venture Capital Yearbook", we divide the investment industries into the Internet, cultural media, medical and health, IT and information technology, high-tech industries, manufacturing, chemical industry, energy and construction, agriculture, animal husbandry and food, automobile industries and there are eleven other categories (code 1-11). The formula for calculating the degree of regional specialization is $\mathrm{HHI}=$ $\sum P_{j}^{2}$, where $P_{j}$ is the geographic gap between the fund establishment address and the invested company. The variable for the same province is set to " 1 ", and the variable for different provinces is set to " 0 ". It can be seen that the above HHI value is between 0 and 1 . The higher the HHI value, the higher the degree of specialization, that is, the more concentrated investment.

\section{(3) Control variable}

Taking into account the influence of fund background, we exclude foreign-funded venture capital funds, and only focus on venture capital funds with local background. For the investment stage, we choose the investment stage as the expansion period investment and exit events. Regarding the establishment time of venture capital funds, we select private equity venture capital funds whose establishment dates are from 2008 to 2018 .

\section{RESULT}

\subsection{Descriptive statistics}

This section carries out a descriptive statistical analysis of the main variables, as shown in Table 2 . It can be seen that the distribution of investment returns is relatively concentrated, while the investor experience is a certain skewed distribution (the median and the average are larger and the variance is larger), and the part with smaller value is more concentrated and the value is larger. The place is sparsely distributed. From the performance of industry correlation, the proportion of funds focusing on a certain industry is relatively large; from the perspective of regional correlation, the proportion of funds focusing on investment in the same region is also more than half, which shows that most funds They all invest in the industries and regions they are familiar with.

Table 2. Descriptive statistics of variables

\begin{tabular}{|c|c|c|c|c|c|c|}
\hline & Average value & Median & Range & Variance & Max & Minimum \\
\hline Investment Return $\left(y_{1}\right)$ & 26.13 & 20.99 & 305.29 & 1461.59 & 205.29 & -100 \\
\hline Investor's experience & 0.8418 & -0.61 & 44.0 & 8.21 & 43.39 & -0.60 \\
\hline Industry Specialization & 0.92 & 1.0 & 0.77 & 0.03 & 1.0 & 0.22 \\
\hline Regional Specialization & 0.97 & 1.0 & 0.5 & 0.0124 & 1.0 & 0.5 \\
\hline
\end{tabular}


(a)

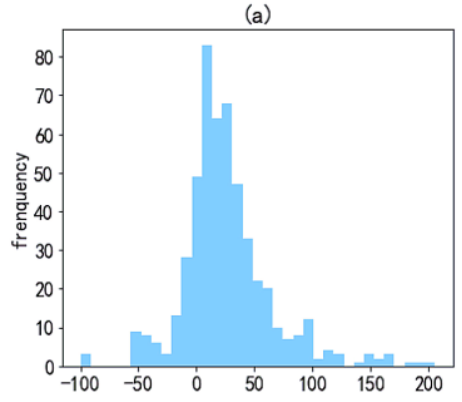

(b)

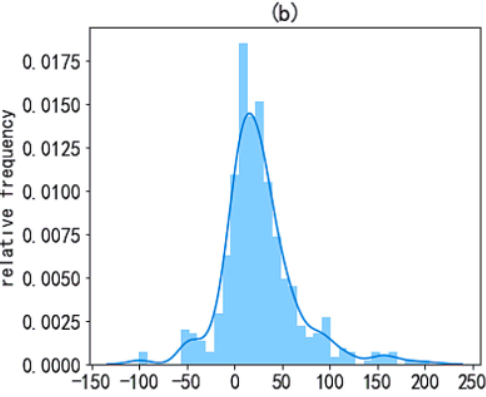

Figure 1 The distribution of the average internal rate of return of the sample funds, the left picture is the frequency, the right picture is the frequency

\subsection{Correlation and significance analysis of variables}

In order to judge the relationship between investment return and each explanatory variable, we analyzed the Pearson correlation coefficient and $\mathrm{P}$ value (correlation/significance level), as shown in Table 3. It can be seen from Table 3 that the correlation between investment returns and investor experience and industry specialization strategies can be accepted with a very high probability ( $\mathrm{P}$ value is less than 0.1 ), which means that the investor experience is richer and the investment industry is highly concentrated. Funds can get better investment returns. On the other hand, the significance index of regional specialization strategy is relatively high $(\mathrm{P}=0.425)$, indicating that the correlation between regional concentration and investment return is not significant. The results support Dang et al. (2014)[19] that regional specialization and investment return are not Related viewpoints. At the same time, the results have also been initially verified for the negative correlation between industry specialization and investment return ( $\mathrm{r}=-0.131)$, and the logarithm of industry specialization is also significantly related to investment return. Therefore, the results support the view that there is a convex relationship between industry specialization and investment returns.

Table 3. Correlation coefficient and $\mathrm{P}$ value of variables

\begin{tabular}{|c|c|}
\hline- & Investment Return \\
\hline Investment Return & - \\
\hline Investor's experience & $-0.100 / 0.020$ \\
\hline Industry Specialization & $-0.131 / 0.002$ \\
\hline
\end{tabular}

\begin{tabular}{|c|c|}
\hline In(Industry Specialization) & $-0.129 / 0.03$ \\
\hline Regional Specialization & $-0.034 / 0.425$ \\
\hline
\end{tabular}

In order to further test the above hypothesis, we will use regression analysis to explore in the next section.

\subsection{Regression test}

As mentioned above, we have built 3 models to test the hypotheses proposed. We perform regression analysis on a single independent variable, and then perform regression analysis on multiple variables at the same time, and give the corresponding regression test results, as shown in Table 4. The variables in Table 4 are the coefficients, intercepts, adjusted square values and test statistics of the variables in the model. Among them, investor experience has a significant positive correlation effect on investment returns at the level of significance of $5 \%$. Industry specialization has a negative impact on investment returns at the level of significance of $5 \%$, indicating that diversified investment strategies are easier to obtain higher returns than professional investment strategies. In model (3), the logarithm of industry specialization is positively correlated with investment returns, indicating that there is a convex relationship between industry specialization and investment returns. In terms of regional specialization, because the p-value is too high, it is impossible to accept its hypothesis related to investment returns at a significance level of $10 \%$, that is, $\mathrm{H} 3$ does not hold. Therefore, we believe that there is no statistical correlation between regional specialization strategies and investment returns.

Table 4. Regression test results

\begin{tabular}{|c|c|c|c|}
\hline Variable & Model 1 & Model 2 & Model 3 \\
\hline Investor's experience & 1.33 & 0.851 & 0.864 \\
\hline Industry Specialization & & -27.29 & -48.366 \\
\hline Regional Specialization & & 18.14 & 18.199 \\
\hline In(Industry Specialization) & & & 14.123 \\
\hline General form & 25.01 & 33.04 & 54.017 \\
\hline Observations & 540 & 540 & 540 \\
\hline
\end{tabular}




\begin{tabular}{|l|l|l|l|}
\hline Adjust $R^{2}$ & 0.008 & 0.022 & 0.022 \\
\hline F statistics & 6.274 & & \\
\hline
\end{tabular}

\subsection{Robustness test}

We conduct a robustness test on the relationship between the characteristics of venture capital funds, investment strategies and investment returns to test whether the above conclusions are consistent in different investment return measures. The results of the robustness test are shown in Table 5. We use the average book return value of venture capital funds as a proxy variable for investment returns. While keeping other variables unchanged, repeat the regression analysis of model (3).

Table 5. Robustness test results

\begin{tabular}{|c|c|c|c|c|c|}
\hline $\begin{array}{c}\text { Investor's } \\
\text { experience }\end{array}$ & Industry Specialization & $\begin{array}{c}\text { Regional } \\
\text { Specialization }\end{array}$ & $\begin{array}{c}\text { In(Industry } \\
\text { Specialization) }\end{array}$ & General form & Adjust $R^{2}$ \\
\hline 0.0574 & -10.437 & 1.61 & 5.766 & 11.129 & 0.030 \\
\hline
\end{tabular}

It can be seen from the above table that industry specialization is significant at the level of $10 \%$, and is negatively correlated with average book returns, while the logarithm of industry specialization is positively correlated with average book returns, which fully demonstrates the stability of the aforementioned verification The results show that there is a convex relationship between industry specialization and investment returns. The model gives the same explanation as when the average internal rate of return is used as the dependent variable, indicating that the model's evaluation method and interpretation ability are more reliable.

\section{DISCUSSION}

Based on the above results, we make the following recommendations. First of all, if the venture capital fund is a management team with rich investment experience, it will benefit its return on investment. Secondly, there is a convex relationship between professional investment strategies and investment returns. When the number of investments reaches a certain threshold, it is better for venture capital institutions to adopt professional investment strategies, and when the number of investments exceeds a certain threshold, diversified investment strategies it shows its advantages. In addition, due to the limitations of data collection and research conditions, this paper has the following shortcomings:

(1) We have fewer choices of characteristic variables of venture capital funds. Due to the limitation of the data content that can be collected, we are temporarily unable to analyse and control more influencing factors. We only conduct research on areas that are currently controversial at home and abroad.

(2) We take part of the characteristics of venture capital funds as independent variables and the result of investment exit as dependent variables. Therefore, it is impossible to avoid some other factors such as the potential impact of post-investment management on the invested company, which may affect the accuracy of the empirical results. Sex brings a certain error. With the improvement of the corresponding venture capital fund data, more characteristics and more control variables can be used in the future to study the factors that affect the investment returns of investment institutions.

\section{CONCLUSIONS}

We empirically study the relationship between some characteristics of venture capital funds and investment returns. Specifically, we study the investor experience of venture capital funds and the impact of fund investment strategies on investment returns. Using correlation analysis and hierarchical regression methods, the following conclusions are drawn: First, the investor experience of venture capital funds is positively correlated with investment returns; second, professional investment strategies are better than diversified investments before a certain investment threshold Strategies, after breaking through the threshold of a certain amount of investment, diversified investment strategies are better than professional investment strategies, that is, there is a convex relationship between professional investment strategies and investment returns; third, there is no regional specialization investment strategy and investment returns relationship. We extend the research of venture capital funds to the background of China and provide guidance for fund managers on how to better adopt investment strategies and how investors choose high-quality venture capital funds.

\section{REFERENCES}

[1] Qian Ping, Zhang Wei. Returns on Chinese Venture Capital investment and its determinants [J]. Economic Research Journal, 2007, 5: 78-90. (in Chinese)

[2] Du J, Meng J, Yuan C. Spatial Distribution and Exit Performance of Risk Investment in China. Finance \& Economics, 2019(08):26-41. (in Chinese) 
[3] Xu Mengzhou. Venture capital firms' strategy choice and performance [D]. Zhejiang: Zhejiang Univ., 2010: 1-3. (in Chinese)

[4] Mai Y, Ran A, Zhang W, et al. Top Management Team Faultline of Venture Capitalist and Investment Performance[J]. Academy of Management Annual Meeting Proceedings, 2016, 2016(1):13488.

[5] STEVEN, N, KAPLAN, et al. Which CEO Characteristics and Abilities Matter?[J]. Journal of Finance, 2012.

[6] Siqueira E, Carvalho A, Netto H G. Determinantes do Sucesso dos Investimentos de Private Equity e Venture Capital no Brasil[J]. Ssrn Electronic Journal, 2011, 9:189-208.

[7] Zarutskie R. The role of top management team human capital in venture capital markets: Evidence from first-time funds[J]. Journal of Business Venturing, 2010, 25(1):155-172.

[8] Nan J, Wei L. Specialization and performance: Evidence from Chinese venture capital funds[C]// International Conference on Management Science \& Engineering Conference. IEEE, 2014: 15041511.

[9] Xi H. The Specialization Choices and Performance of Venture Capital Funds[J]. Social Science Electronic Publishing, 2009.

[10] Gompers P, Kovner A, Lerner J. Specialization and Success: Evidence from Venture Capital[J]. Journal of Economics \& Management Strategy, 2010, 18(3):817-844.

[11] Bottazzi L, MD Rin, Hellmann T. Who are the active investors?: Evidence from venture capital[J]. Journal of Financial Economics, 2008, 89(3):488512.

[12] Srensen M. How Smart is Smart Money? A TwoSided Matching Model of Venture Capital[J]. The Journal of Finance, 2007, 62(6):2725-2762.

[13] Bengtsson O, Sensoy B A. Investor abilities and financial contracting: Evidence from venture capital[J]. Journal of Financial Intermediation, 2011, 20(4):477-502.

[14] Fang H, Nofsinger J R, Song Z, et al. Private equity performance and capital flows: Evidence from China[J]. Emerging Markets Review, 2018, 37.

[15] Gompers P, Kovner A, Lerner J. Specialization and success: Evidence from venture capital[J]. Journal of Economics \& Management Strategy, 2009, 18(3): 817-844.
[16] Deng Chao, Liu Yihan. The impact of VC's industry specialization investment intensity on corporate innovation capability[J]. Science \& Technology Progress and Policy, 2017, 34(05): 8085. (in Chinese)

[17] Huang F G, Wang J Y, Zhu G L. The specialization investment of venture capital and the technology innovation of the invested enterprises[J]. Studies in Science of Science, 2016, 34(12): 1875-1885. (in Chinese)

[18] Li Yan, Zhuang Xintian, Luo Guofeng, et al. Venture Capital Investment Strategy and Performance — Based on the Empirical Research of Chinese Venture Capital Institutions[J]. Review of Investment Studies, 2012,31(11): 88-100. (in Chinese)

[19] Dang X, Chen Z, Wang Y. Specialization and Performance of Venture Capital Firms —-Data From the Chinese Venture Capital Industry[J]. Science \& Technology Progress and Policy, 2014, 31(12): 7-11. (in Chinese)

[20] Shen W T, Hu L T, Management S O, et al. Research on the Influence of Specialization Investment Strategies on Venture Capital Investment Performance[J]. Journal of Shanxi Finance and Economics University, 2014, 36(05): 42-53. (in Chinese)

[21] Bartkus J R, Hassan M K. Specialization versus diversification in venture capital investing[J]. Journal of Financial Regulation and Compliance, 2009.

[22] Buchner A, Mohamed A, Schwienbacher A. Diversification, risk, and returns in venture capital[J]. Journal of Business Venturing, 2017, 32(5): 519-535.

[23] Norton E, Tenenbaum B H. Specialization versus diversification as a venture capital investment strategy[J]. Journal of Business venturing, 1993, 8(5): 431-442.

[24] Kanniainen V, Keuschnigg C. Start-up investment with scarce venture capital support[J]. Journal of Banking \& Finance, 2004, 28(8):1935-1959.

[25] Matusik S F, Fitza M A. Diversification in the venture capital industry: leveraging knowledge under uncertainty[J]. Strategic Management Journal, 2012, 33(4): 407-426.

[26] Ahuja G, Katila R. Technological acquisitions and the innovation performance of acquiring firms: A longitudinal study[J]. Strategic management journal, 2001, 22(3): 197-220. 
[27] March J G. Exploration and exploitation in organizational learning $[\mathrm{J}]$. Organization science, 1991, 2(1): 71-87.

[28] Gavetti G, Levinthal D A, Rivkin J W. Strategy making in novel and complex worlds: The power of analogy $[\mathrm{J}]$. Strategic Management Journal, 2005, 26(8): 691-712.

[29] Ni Zhengdong, Sun Liqiang. A sudy on the Venture Capital Returns in China[J]. China Soft Science Magazine, 2008, 4: 48-56. (in Chinese)

[30] Liu Y. Private Equity Fund Performance Determinants: Evidence From Fund Characteristics. lutpub, 2014.

[31] Lanfang Wang, Susheng Wang. The Impact of Public Market Signals on Venture Capital Investment Decision and Performance[J]. China Economic Quarterly, 2011, 10(01):183-208. 